\title{
ТЕОРЕТИКО-МЕТОДИЧНІ ТА ПРАКТИЧНІ ЗАСАДИ ЩОДО РОЗРОБЛЕННЯ ТА ВПРОВАДЖЕННЯ СПЕЦІАЛІЗОВАНИХ СКЛАДОВИХ МЕДИЧНОГО ЕЛЕКТРОННОГО ПАСПОРТА ЛЮДИНИ
}

\author{
В. П. Карленко ${ }^{1}$, О. П. Мінцер, О. В. Сарканич ${ }^{2}$ Б. В. Карленко ${ }^{1}$ \\ Національна медична академія післядипломної освіти імені П. Л. Шупика \\ ${ }^{1}$ Національний університет фрізичного виховання і спорту України \\ ${ }^{2}$ ТОВ «Сузір'я» Санаторій «Квітка полонини»
}

\begin{abstract}
Розглянуто доцільність та можливість створення спеціалізованих паспортів людини. Запропонована біоенергетична складова медичного електронного паспорта людини, що може знайти широке застосування в медичних профрілактичних і лікувальних установах різного профілю, на підприємствах, у спортивних та інших закладах при автоматизованій оцінці функціонального стану окремих людей, а також при статистичних дослідженнях і визначенні різних соціальних генотипічних груп населення за їхніми фрізичними, інтелектуальними та професійними здібностями. Виявлено дев'ять найбільш ефективних показників енергозабезпечення м'язової діяльності людини, розроблено п'ятибальну систему оцінювання їхніх параметрів і встановлено п'ять біоенергетичних груп, до яких відносяться люди з достовірно різними індивідуальними рівнями енергозабезпечення організму.
\end{abstract}

Ключові слова: медичний електронний паспорт (МЕП), спеціалізована інформація МЕП, біоенергетика, біоенергетична складова МЕП, орункціональні та резервні можливості організму, енергозабезпечення організму.

\section{THEORETICAL AND METHODICAL, AND PRACTICAL FRAMEWORK FOR THE DEVELOPMENT AND IMPLEMENTATION OF SPECIALIZED COMPONENTS OF THE MEDICAL ELECTRONIC PASSPORT OF THE PERSON}

\author{
V. P. Karlenko'1, O. P. Mintser, O. V. Sarkanych², \\ Shupyk National Medical Academy of Postgraduate Education \\ ${ }^{1}$ National University of Physical Education and Sports of Ukraine \\ ${ }^{2}$ «Suzir'ya» Ltd Spa resort «Kvitka Polonyny»
}

B. V. Karlenko ${ }^{1}$

\begin{abstract}
The expediency and the possibility of creation of specialized passports of a person are considered. It is proposed bioenergy component of the medical electronic passport, which can be widely used in preventive and medical institutions of various profiles, at enterprises, at sports and other institutions, with an automated assessment of the functional status of individuals, as well as in statistical studies and the identification of different social genotypic populations by their physical, intellectual and professional abilities. The nine most effective indicators of power supply of muscular activity of the person were revealed, a five-point system of estimation of their parameters was developed and five bioenergetic groups were identified, which include people with significantly different individual levels of energy supply of the organism.
\end{abstract}

Key words: medical electronic passport (MEP), specialized information of MEP, bioenergetics, bioenergetic component of MEP, functional and reserve capabilities of an organism, energy supply of an organism. 


\title{
ТЕОРЕТИКО-МЕТОДИЧЕСКИЕ И ПРАКТИЧЕСКИЕ ОСНОВЫ ПО РАЗРАБОТКЕ И ВНЕДРЕНИЮ СПЕЦИАЛИЗИРОВАННЫХ СОСТАВЛЯЮЩИХ МЕДИЦИНСКОГО ЭЛЕКТРОННОГО ПАСПОРТА ЧЕЛОВЕКА
}

\author{
В. П. Карленкоㄱ, О. П. Минцер, А. В. Сарканыч², Б. В. Карленко ${ }^{1}$ \\ Национальная медицинская академия последипломного образования имени П. Л. Шупика \\ ${ }^{1}$ Национальный университет фризического воспитания и спорта Украины \\ ${ }^{2} \mathrm{OOO}$ «Сузирья» Санаторий «Квитка полоныны»
}

\begin{abstract}
Рассмотрена целесообразность и возможность создания специализированных паспортов человека. Предложена биоэнергетическая составляющая медицинского электронного паспорта человека, которая может найти широкое применение в медицинских профрилактических и лечебных учреждениях различного профиля, на предприятиях, в спортивных и других заведениях при автоматизированной оценке функционального состояния отдельных людей, а также при статистических исследованиях и определении различных социальных генотипических групп населения по их фризическим, интеллектуальным и профессиональным способностям. Выявлено девять наиболее эфрфективных показателей энергообеспечения мышечной деятельности человека, разработана пятибалльная система оценки их параметров и установлены пять биоэнергетических групп, к которым относятся люди с подлинно различными индивидуальными уровнями энергообеспечения организма.
\end{abstract}

Ключевые слова: медицинский электронный паспорт (МЭП), специализированная инорормация МЭП, биоэнергетика, биоэнергетическая составляющая МЭП, фрункциональные и резервные возможности организма, энергообеспечение организма.

Вступ. Раніше групою авторів була проведена велика робота зі створення медичного електронного паспорта (МЕП) громадянина [1, 4, 5, 8, 11]. Стверджувалося, що мобільний документ, який віддзеркалює стан здоров’я людини та доступний для читання (зрозуміло, при відповідному дозволі власника паспорта в будь-якій точці світу), дозволив би суттєво змінити на краще управління охороною здоров'я за рахунок:

- надання об'єктивізованої динамічної картини структури здоров'я населення з виділенням груп ризику і локалізацією їхнього місцезнаходження і професійної діяльності;

- обгрунтування індивідуалізованої профілактики захворювання на стадії, коли ще можливе повернення стану основних систем організму до норми;

- створення принципово нового електронного документу з розподіленням прав і обсягу доступу для лікуючого лікаря, лікаря швидкої і невідкладної допомоги, провізора, страхового товариства і самого пацієнта;

- організації ефективної системи взаєморозрахунків при наданні медичних послуг населенню, включаючи аптечне обслуговування;

- підвищення економічної обгрунтованості медичного страхування і зниження витрат завдяки достовірності вихідної діагностичної інформації;

- обгрунтованого планування в умовах обмеженості фінансових ресурсів найбільш доцільних програм оздоровлення населення в конкретних регіонах (областях, районах, містах).

На жаль, практично розроблений та готовий до впровадження МЕП не знайшов свого місця в організації охорони здоров'я, але до теперішнього часу не втратив своєї актуальності. Більш того, завдяки новим науковим дослідженням, зокрема в галузях геноміки, протеоміки, метаболоміки, тобто індивідуалізації лікувально-діагностичних дій, набуває нової акцентуації.

Доцільність паспортизації фізіологічного стану людини обумовлена, з одного боку, у контексті взаємозв'язку існуючих медико-біологічних, соціальних, психологічних, біоенергетичних та інших теорій, відповідно до яких життєдіяльність окремого індивіда як біологічної і соціальної істоти, групи людей і суспільства обумовлюється єдністю процесів збалансованого існування та реалізації ними життєвих потреб і можливостей, що забезпечують багаторічну, поточну та оперативну працездатність у поєднанні біоенергетичних процесів з формами проявів самобутності людини. 3 іншого боку, необхідність паспортизації фізіологічного стану людини зумовлена потребою узагальнення накопичених наукових даних щодо закономірностей розвитку людини в онтогенезі та їх використання з метою оптимізації процесу її повсякденної життєдіяльності.

Окремими науковцями доведено, що через призму процесів енергозабезпечення забезпечується безперервність перетворення на клітинному рівні 
зовнішніх і внутрішніх джерел енергії у субстрати, які використовуються для функціонування окремих органів, систем та організму в цілому, кожна клітина якого забезпечує свої енергетичні потреби за рахунок зовнішніх ресурсів, що відрізняються суттєвою різноманітністю.

В інших дослідженнях встановлено, що енергія для забезпечення фізіологічної діяльності окремих органів, систем (зокрема м’язової і серцево-судинної) і організму в цілому споживається від зовнішніх джерел живлення (вуглеводи, жири і білки) і за допомогою кисню перетворюється на фізичну або інтелектуальну роботу [14-16].

Отже, життєдіяльність людини, що характеризується перш за все її працездатністю, з одного боку обумовлена генотипічними, а з іншого фенотипічними чинниками, що взаємопов'язані та взаємозалежні. При цьому працездатність людини зумовлена рівнем енергозабезпечення ії̈ організму i бережливим використанням енергетичних ресурсів, а також ступенем збалансованості процесів репродукції і утилізації енергії в умовах повсякденної діяльності.

Важливим чинником, що зумовлює ефективність життєдіяльності людини, є психічні властивості, рівень яких визначається ступенем її стійкості в умовах стресу. Таке ствердження коректно співвідноситься $з$ окремими положеннями біологічної концепції стресу, розробленої Гансом Сельє у 1936 році, згідно з якими встановлено, що однією з головних функцій психіки людини $є$ врівноваження діяльності організму з постійно змінними умовами зовнішнього середовища, а психічні процеси по суті є проявом фізіологічних процесів, що обумовлені, зі свого боку, біоенергетикою діяльності людини на клітинному рівні.

Проте, зазначені наукові дані та результати досліджень інших авторів свідчать про суто диференційований підхід для оцінки та характеристики різних проявів життєдіяльності людини та їх переважну однобічність.

Саме тому подальше удосконалення професійної та соціальної діяльності людини потребує застосування доступних підходів, зокрема інтегрованого, для визначення дієвих засобів, методів та способів такого удосконалення в умовах урбанізованого суспільства. В інтегрованому підході мають ураховуватися закономірності взаємозв’язку щоденних поведінкових проявів особистості з рівнем іiї енергозабезпечення, на засадах яких доцільно розробити відповідні алгоритми для інтегровано-диференційованої оцінки ознак життєдіяльності людини, що притаманні тому чи іншому виду професійної і соціальної діяльності.

Таке припущення грунтується на вимогах часу щодо удосконалення діяльності людини у різних виробничих сферах, зумовленого високим ступенем зайнятості та підвищеним рівнем професійних навантажень на сучасному етапі розвитку суспільства, шляхом активізації свідомості людини щодо потреби ефективного використання власних здібностей упродовж певного періоду життя. Це потребує застосування нових діагностичних технологій для комплексного контролю за довгостроковим, поточним і оперативним функціональним станом органів, систем та організму людини в цілому, однією з яких може бути розроблення та впровадження біоенергетичного паспорта людини.

Передбачалося, що розроблення біоенергетичного паспорта людини на основі використання сукупних знань щодо медико-біологічних, психологічних і соціальних закономірностей функціонування людського організму з урахуванням індивідуальних закономірностей його енергозабезпечення забезпечить:

- визначення індивідуального біоенергетичного, медичного, соціального, психологічного та професійного профілів людини;

- оптимізацію професійної діяльності людини;

- створення науково-методичних та практичних засад для керування життедіяльністю та працездатністю людини в макро-, мезо- та мікроінтервалах часу соціального середовища.

Мета роботи: визначення можливості створення та обгрунтування структури спеціалізованої біоенергетичної складової МЕП.

Матеріали та методи дослідження. Для проведення досліджень в різних умовах соціального середовища використовувався комплекс педагогічних, медико-біологічних, психологічних та кінезіологічних методів дослідження діяльності людей різного віку, статі та професійної належності, серед яких - аналіз науково-методичної та спеціальної літератури; вивчення різновидів поведінки людей у соціальному середовищі та їх узагальнення; педагогічні спостереження за їхньою повсякденною спортивною та оздоровчою діяльністю; бесіди із застосуванням методів експертних оцінок; навантажувальні тести з проведенням газоаналізу, визначенням показників споживання кисню та зон інтенсивності роботи; біохімічний аналіз крові для контролю за рівнем гемоглобіну, гематокриту, 
сечовини, молочної кислоти, креатинкінази; електрокардіографія. Отримані результати дослідження оброблені відомими математико-статистичними методами з визначенням $\mathrm{X}, \pm \mathrm{M}, \pm \mathrm{g}, \mathrm{CV}$.

Для розроблення біоенергетичного паспорта людини використовувалася авторська методика «D\&K-TEST» (патент на винахід № 57675 від 29 жовтня 2002 року «Спосіб експрес-діагностики функціонального стану і резервних можливостей організму та пристрій для його реалізації» [12]), в основу якої покладено вимір амплітуд зубців R та S за методикою Вільсона у модифікації [5].

У програмному забезпеченні, що є невід'ємною частиною зазначеного винаходу, за формулою у грудних відведеннях V3R, V1, V2, V4, V5, V6 передбачено реєстрацію висоти зубця R та глибини зубця S протягом 12-15 с; визначення метаболічної ємності кожного грудного відведення шляхом обчислення співвідношення усереднених значень висоти зубця R та глибини зубця $\mathrm{S}$ за формулою (R/ $\mathrm{R}+\mathrm{S}) \cdot 100 \%$ з одночасним диференціюванням висоти зубця R та глибини зубця $\mathrm{S}$ до першої похідної у грудних відведеннях V3R (на рівні V3 справа від груднини), V2, V6; розрахунки показників та параметрів рівня енергозабезпечення людини; формування індивідуального протоколу дослідження людини, в якому за допомогою соціальних та біоенергетичних алгоритмів визначають приналежність людини до певної біоенергетичної групи, її біоенергетичний, медичний, психологічний, професійний та соціальний профілі, а також надаються відповідні рекомендації щодо оптимізації діяльності людини у повсякденному соціальному середовищі.

Дослідження проводили з 1978 року по цей час, у них взяли участь близько 4000 осіб різних вікових груп, статі та професій. Їх тестування здійснювалось в клінічних, лабораторних і побутових умовах, у стані спокою і після фізичних навантажень, упродовж інфекційних і застудних захворювань, в різні цикли специфічного біологічного циклу у жінок, у періоди відновлення людини протягом робочого дня, під час участі у фізкультурно-оздоровчих заходах, тренуваннях, змаганнях різних рівнів (регіональні, всеукраїнські, всесвітні студентські ігри, континентальні, чемпіонати світу, Олімпійські ігри). В цілому проведено понад 30000 тис. людино-досліджень, в яких проаналізовано близько 700 тис. зубців R i S електрокардіограми.

Результати та їх обговорення. Досліджено біоенергетичні показники і параметри енергозабезпечення діяльності людини (табл. 1).
Аналіз динаміки зазначених у табл. 1 показників свідчить про їх індивідуальний генез, високий ступінь зв’язку з проявами людської діяльності, достовірність якого оцінювалася респондентами 3 використанням методу експертних оцінок та коливалася в межах 75-95 \% від суб'єктивного розуміння особистої сутності такої діяльності.

Одними з таких біоенергетичних параметрів являються анаеробна (ANAMC), аеробна (AMC) і загальна (GMC) метаболічні ємності.

Анаеробна метаболічна ємність (ANAMC) характеризує здатність до виконання інтенсивних навантажень різного типу на межі можливостей організму. Обчислюється як середня сума процентних відношень $(\mathrm{R} / \mathrm{R}+\mathrm{S}) \cdot 100$ \% у грудних відведеннях V3R, V1 і V2.

Аеробна метаболічна ємність (АМС) характеризує ємність аеробного джерела енергозабезпечення роботи м’язів, що визначає здатність до тривалого виконання фізичних та інших типів навантажень помірної інтенсивності. Обраховується як середня сума процентних відношень (R/R+S)·100 \% у грудних відведеннях V4, V5 і V6.

Загальна метаболічна ємність (GMC) являється одним $з$ найбільш важливих параметрів функціональної підготовленості організму. Вона характеризує генетично наперед визначений рівень можливостей організму і може бути оцінкою працездатності. Обчислюється як сума ANAMC i AMC.

Іншими важливими біоенергетичними параметрами являються потужність креатинфосфатного (CPH) і гліколітичного (GL) джерел енергозабезпечення роботи м’язів, які визначаються подібним чином, але за даними відведень V3R i V2 диференційованої електрокардіограми (dEKG) відповідно за формулою $(\mathrm{R} / \mathrm{R}+\mathrm{S}) \cdot 100$ \%. При обчисленні показників CPH i GL беруть до уваги найбільшу амплітуду зубця R. Показник СРН свідчить про швидкість і динамічну силу, які прямо залежать від максимальних витрат в скелетних м’язах креатинфосфату як джерела енергозабезпечення в умовах короткочасної роботи до виснаження, а за допомогою біоенергетичного показника GL оцінюється потенціальна можливість максимального накопичення молочної кислоти в крові, що характеризує витривалість організму.

Наступним не менш важливим параметром являється потужність аеробного джерела енергозабезпечення (MOC), іншими словами - максимальне споживання кисню, яке традиційно визначається 
Показники енергозабезпечення організму людини, визначені за методикою «D\&K-TEST»

\begin{tabular}{|c|c|}
\hline Показник & Характеристика показника \\
\hline $\begin{array}{c}\text { ANAMC — анаеробна метаболічна } \\
\text { ємність }\end{array}$ & $\begin{array}{c}\text { Здатність організму людини до виконання загального обсягу } \\
\text { роботи (переважно високоінтенсивна) }\end{array}$ \\
\hline AMC — аеробна метаболічна ємність & $\begin{array}{r}\text { Здатність організму до виконання } \\
\text { (переважно малоін }\end{array}$ \\
\hline GMC — загальна метабол & $\begin{array}{c}\text { Обумовлює здатність людини до виконання загального обсягу } \\
\text { фізичних, інтелектуальних та інших навантажень, їі дієздатність } \\
\text { та працездатність }\end{array}$ \\
\hline ANAMC/GMC — анаероб & $\begin{array}{r}\text { Визначає анаеробний гено } \\
\text { процесів анаеробної утиліз }\end{array}$ \\
\hline AMC/GMC - аеробна с & $\begin{array}{r}\text { Визначає аеробний ген } \\
\text { цесів аеро }\end{array}$ \\
\hline $\begin{array}{c}\text { СРН — потужність креатинфосфатного } \\
\text { джерела енергозабезпечення м’язової } \\
\text { роботи }\end{array}$ & $\begin{array}{c}\text { Детермінує силову витривалість, вибухову силу, реактивність, } \\
\text { темперамент }\end{array}$ \\
\hline $\begin{array}{l}\text { GL — потужність гліколітичного джере- } \\
\text { ла енергозабезпечення м’язової роботи }\end{array}$ & $\begin{array}{r}\text { Детермінує рівень спеціаль } \\
\text { продуктивну та ути } \\
\end{array}$ \\
\hline $\begin{array}{c}\text { МОС - потужність аеробного джерела } \\
\text { енергозабезпечення м’язової роботи }\end{array}$ & $\begin{array}{r}\text { Визначає якість виконання фізичних та інших наг } \\
\text { аеробної спрямованості до настання втоN }\end{array}$ \\
\hline $\begin{array}{l}\text { TAN - ефективність використання } \\
\text { аеробного джерела енергозабезпечення } \\
\text { м’язової роботи до настання втоми }\end{array}$ & $\begin{array}{c}\text { Детермінує економічність використання енергетичних субстра- } \\
\text { тів, здатність до навчання, координаційні здібності, професійну } \\
\text { та соціальну гнучкість }\end{array}$ \\
\hline $\begin{array}{l}\text { HR on the TAN — частота серцевих ско- } \\
\text { рочень на межі анаеробного обміну }\end{array}$ & $\begin{array}{c}\text { Критерій ефективності використання аеробного джерела енер- } \\
\text { гозабезпечення м’язової роботи, визначає пульсові межи зон } \\
\text { інтенсивності професійних та фізичних навантажень різної } \\
\text { потужності }\end{array}$ \\
\hline
\end{tabular}

методом ергоспірометрії і оцінкою вмісту молочної кислоти в крові. При традиційному методі також необхідні навантажувальні тести. Цей параметр вимірюється в мілілітрах за хвилину, віднесених до маси тіла досліджуваного. Запропонованим непрямим способом МОС визначається за допомогою диференційованої до першої похідної електрокардіограми (dEKG). Спочатку вимірюють амплітуди зубців R i S, а потім розраховують за формулою $(\mathrm{R} / \mathrm{R}+\mathrm{S}) \cdot 100$ \%. При цьому використовують дані лівого грудного відведення V6. Похибка становить не більше 10 \%. Фактор аеробної потужності використовують для швидкої оцінки раціонального використання засобів і методів максимізації кардіо-респіраторної продуктивності. Цей показник визначає якість виконання фізичних та інших навантажень аеробної спрямованості до рівня порога анаеробного обміну, а також загальну витривалість організму.

Показник TAN — ефективність використання аеробного джерела енергозабезпечення м'язової роботи, або аеробна економічність, — запропонованим непрямим способом може бути визначений відношенням R/R+S до dEKG у відведеннях V2 i V6. Величину TAN у відсотках від МOC одержують в результаті ділення величини TAN у V6 на середню суму цих відношень у V2 і V6.

Вивчення динаміки показників і параметрів МЕП людини в умовах повсякденної діяльності свідчить, що важливими показниками, які визначають біоенергетичні характеристики досліджуваного організму, являються процентні відношення анаеробної (ANAMC) і аеробної (AMC) метаболічних ємностей до загальної метаболічної ємності (GMC), тобто ANAMC/GMC і AMC/GMC, які є основними ознаками, що відрізняють запропонований спосіб експрес-діагностики.

За цими показниками можна оцінювати генотипічні особливості організму, що характеризуються його біоенергетичним потенціалом.

Визначення працездатності за факторами ANAMC, AMC, GMC, CPH, GL, MOC, TAN, ANAMC/GMC та AMC/GMC дозволяє обгрунтовано регламентувати обсяг професійного 
Порівняльні дані показників енергозабезпечення людей різного віку та статі (чоловіки - 1886 осіб, жінки - 1377 осіб)

\begin{tabular}{|c|c|c|c|c|}
\hline \multirow{2}{*}{ Показник } & \multirow{2}{*}{ Стать } & \multicolumn{3}{|c|}{ Статистичний параметр, ум. од. } \\
\hline & & $\mathrm{X}$ & $\pm \mathrm{g}$ & $\mathrm{p}$ \\
\hline \multirow{2}{*}{ ANAMC/GMC } & ч & 23,4 & 7,8 & \multirow{2}{*}{$>0,05$} \\
\hline & ж & 24,0 & 7,2 & \\
\hline \multirow{2}{*}{$\mathrm{AMC} / \mathrm{GMC}$} & ч & 76,4 & 8,5 & \multirow{2}{*}{$>0,05$} \\
\hline & ж & 75,9 & 7,4 & \\
\hline \multirow{2}{*}{ ANAMC } & 4 & 77,1 & 33,1 & \multirow{2}{*}{$>0,05$} \\
\hline & ж & 81,3 & 30,3 & \\
\hline \multirow{2}{*}{ AMC } & ч & 245,7 & 35,2 & \multirow{2}{*}{$>0,05$} \\
\hline & ж & 251,5 & 32,8 & \\
\hline \multirow{2}{*}{ GMC } & ч & 322,9 & 47,0 & \multirow{2}{*}{$>0,05$} \\
\hline & ж & 332,9 & 46,6 & \\
\hline \multirow{2}{*}{$\mathrm{CPH}$} & 4 & 32,1 & 10,4 & \multirow{2}{*}{$>0,05$} \\
\hline & ж & 34,7 & 8,3 & \\
\hline \multirow{2}{*}{ GL } & ч & 33,0 & 5,1 & \multirow{2}{*}{$>0,05$} \\
\hline & ж & 32,5 & 6,4 & \\
\hline \multirow{2}{*}{ MOC } & ч & 64,1 & 5,9 & \multirow{2}{*}{$>0,05$} \\
\hline & ж & 64,7 & 5,7 & \\
\hline \multirow{2}{*}{ TAN } & ч & 65,9 & 4,6 & \multirow{2}{*}{$>0,05$} \\
\hline & ж & 66,62 & 4,6 & \\
\hline \multirow{2}{*}{ HR on the TAN } & $\mathrm{Y}$ & 163,0 & 10,5 & \multirow{2}{*}{$>0,0$} \\
\hline & ж & 163,9 & 9,2 & \\
\hline
\end{tabular}

навантаження, швидко оцінювати ефективність його впливу на подальший стан людини та її готовність до наступного навантаження (у спортивній та оздоровчій діяльності відтворює ефективність використання засобів і методів розвитку анаеробних та аеробних можливостей, швидкісно-силових якостей, ступінь відновлення організму та стан готовності до проведення наступного тренування).

При порівнянні з фактичними даними, одержаними в клінічних умовах, середня похибка методики «D\&R-TEST» становить $\pm 5 \%$.

Аналіз персональних протоколів дослідження свідчить, що у кожної людини спостерігалися індивідуальні рівні її енергозабезпечення. Тривале порівняння цих показників з даними педагогічного спостереження за учасниками експерименту дозволило нам розробити прогностичний алгоритм відповідності індивідуальних показників енергозабезпечення проявам їхньої повсякденної діяльності.

Системне використання прогностичного алгоритму у процесі застосування показників енергозабезпечення, отриманих з використанням методики «D\&K-TEST» для інтерпретації належності людини до відповідного біоенергетичного медичного, психологічного, професійного та соціального типу особистості без збору додаткової інформації про таку людину, свідчить про високий рівень зв'язку (75-95 \%) цих показників із зворотною інформацією респондентів щодо особистого розумінням ними свого статусу відповідно до сучасних уявлень медицини, біології, психології, біоенергетики та інших наук. Такі дані дозволили зробити висновок щодо високої прогностичної цінності методики «D\&K-TEST».

Дослідження взаємозв'язку показників і параметрів енергозабезпечення людини в умовах повсякденної діяльності шляхом узагальнення абсолютних показників у людей різного віку та статі показало, що між їхніми середньо-груповими показниками відсутня достовірна різниця, що забезпечує універсальне використання цих показників без уведення додаткових коефіцієнтів (табл. 2).

Подальший статистичний аналіз динаміки багаторічних досліджень показників енергозабезпечення людей різного віку, статі та соціального статусу дозволив розробити спеціальну номограму інтегральної оцінки енергозабезпечення діяльності людини та/або стану функціональних і резервних 


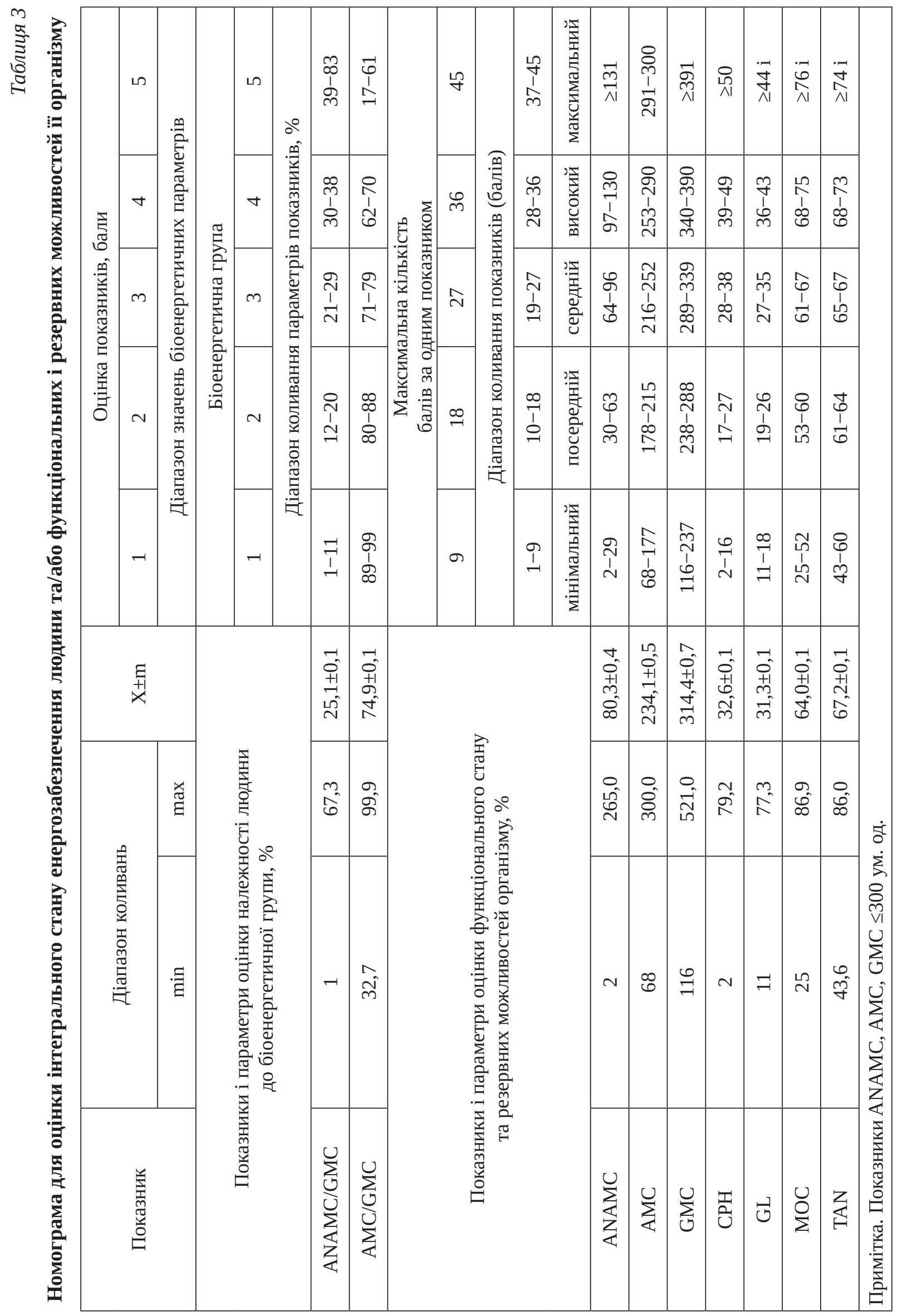


можливостей організму, в якій наведені їхні середньостатистичні (нормативні) значення, межи коливань та параметри оцінки за п’ятибальною системою (табл. 3).

Кожен із 9 показників, крім HR on the TAN, має п’ять діапазонів значень (від одно- до п’ятибального), які визначають рівень функціональних можливостей (мінімальний, посередній, середній, високий, максимальний) та обумовлюють біоенергетичну групу, до якої відноситься та чи інша людина. Таким чином, загальна кількість балів коливалася від 9 до 45.

Належність людини до певної біоенергетичної групи визначалася за допомогою показників, які характеризуються процентними відношеннями ANAMC/GMC та AMC/GMC. Загальна кількість цих груп становить 5. При цьому, як показали дослідження, чим більший номер біоенергетичної групи, тим більшу перевагу вона має у рівні працездатності та можливостей щодо високих професійних здобутків.

3 метою виявлення динаміки розбіжностей показників у людей, які відносяться до певної біоенергетичної групи, проведено спеціальні дослідження, в них брали участь спортсмени, які займалися різними видами спорту та відносяться до такої соціальної категорії, де спостерігаються найбільш екстремальні форми прояву їхньої повсякденної життєдіяльності та працездатності.

Результати досліджень, наведені у табл. 4, свідчать, що зі збільшенням номеру біоенергетичної групи у послідовності від першої до п’ятої, до якої належали спортсмени, спостерігалося достовірне збільшення показників ємності і потужності джерел енергозабезпечення м'язової діяльності, таких як ANAMC, GMC, CPH та GL, які відповідно до наших спостережень у повсякденній діяльності забезпечують високу працездатність людини в умовах роботи максимальної і високої інтенсивності. Водночас із збільшенням номеру біоенергетичної групи у зазначеній вище послідовності спостерігалося достовірне зменшення показників ємності і потужності джерел енергозабезпечення м’язової діяльності, таких як AMC, MOC та TAN, що забезпечують у повсякденній діяльності високу працездатність переважно в умовах середньої та мінімальної інтенсивності.

Наведені експериментальні дані свідчать про різнонаправлений характер взаємозв’язку працездатності спортсменів з показниками енергозабезпечення їхньої м’ язової діяльності, що обумовлене, на наш погляд, генетичною схильністю людини до певного виду фізичної діяльності.

Таблиця 4

Показники енергозабезпечення людей різних біоенергетичних груп (на прикладі різних видів спорту), ум. од.

\begin{tabular}{|c|c|c|c|c|c|c|c|c|c|c|c|c|}
\hline 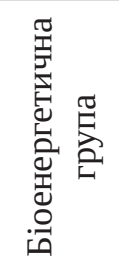 & $\mathrm{n}$ & 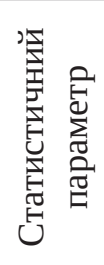 & 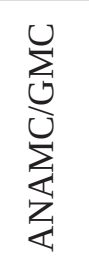 & 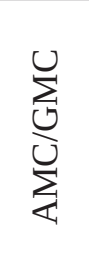 & 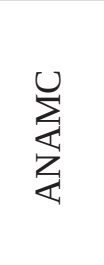 & $\sum_{i}^{U}$ & $\sum_{U}^{U}$ & 荵 & ن & $\begin{array}{l}U \\
\sum\end{array}$ & $\underset{\xi}{Z}$ &  \\
\hline \multirow{2}{*}{5} & \multirow{2}{*}{119} & X ср & 40,9 & 59,1 & 148,8 & 212,8 & 361,6 & 48,6 & 41,3 & 62,5 & 60,5 & 164,2 \\
\hline & & $\pm \mathrm{M}$ & 0,6 & 0,6 & 3,5 & 3,3 & 5,8 & 1,2 & 0,9 & 0,8 & 0,6 & 1,2 \\
\hline \multirow{2}{*}{4} & \multirow{2}{*}{495} & X ср & 32,1 & 67,9 & 112,9 & 236,9 & 349,8 & 40,1 & 35,6 & 67,0 & 65,4 & 167,9 \\
\hline & & $\pm \mathrm{M}$ & 0,2 & 0,2 & 1,1 & 1,5 & 2,2 & 0,4 & 0,3 & 0,32 & 0,2 & 0,5 \\
\hline \multirow{2}{*}{3} & \multirow{2}{*}{1107} & $\mathrm{X} \mathrm{cp}$ & 24,5 & 75,1 & 81,8 & 248,3 & 330,0 & 33,5 & 31,8 & 68,5 & 68,0 & 168,4 \\
\hline & & $\pm \mathrm{M}$ & 0,1 & 0,1 & 0,5 & 0,9 & 1,3 & 0,2 & 0,1 & 0,2 & 0,1 & 0,3 \\
\hline \multirow{2}{*}{2} & \multirow{2}{*}{846} & $\mathrm{X} \mathrm{cp}$ & 17,6 & 82,1 & 54,6 & 250,8 & 305,5 & 32,9 & 32,1 & 68,0 & 67,7 & 167,8 \\
\hline & & $\pm \mathrm{M}$ & 0,1 & 0,2 & 0,7 & 1,0 & 1,4 & 0,2 & 0,1 & 0,2 & 0,1 & 0,3 \\
\hline \multirow[t]{2}{*}{1} & \multirow{2}{*}{241} & $\mathrm{X} \mathrm{cp}$ & 10,1 & 88,7 & 33,1 & 253,8 & 286,9 & 34,4 & 34,2 & 66,4 & 65,8 & 166,4 \\
\hline & & $\pm \mathrm{M}$ & 0,5 & 0,5 & 1,9 & 1,8 & 2,4 & 0,5 & 0,3 & 0,3 & 0,2 & 0,5 \\
\hline \multirow{2}{*}{ Усього } & \multirow{2}{*}{2808} & $\mathrm{X} \mathrm{cp}$ & 23,3 & 76,5 & 77,8 & 252,0 & 323,7 & 35,2 & 33,2 & 67,7 & 67,0 & 169,8 \\
\hline & & $\pm \mathrm{M}$ & 0,2 & 0,2 & 0,7 & 0,6 & 0,9 & 0,2 & 0,1 & 0,1 & 0,9 & 0,2 \\
\hline
\end{tabular}


Підтвердженням тому є більш високі результати спортсменів, які відносяться до 5, 4-ї та 3-ї біоенергетичних груп, на Олімпійських іграх та чемпіонатах світу, де вони здобували в індивідуальних дисциплінах переважно 1-ше-3-тє місця порівняно із здобутками спортсменів 1-ї та 2-ї біоенергетичних груп, які на зазначених змаганнях в індивідуальних дисциплінах посідали переважно місця в трійці призерів та здобували також медалі найвищого гатунку у командних номерах програми.

Цей висновок може бути екстрапольований на діяльність людей з різним ступенем напруженості роботи.

Важливим показником, що також характеризує зв’язок переважної схильності людини до певного типу енергозабезпечення її повсякденної діяльності, $є$ виявлення співвідношення у біоенергетичних групах людей різного віку (табл. 5).

Аналіз матеріалів досліджень, проведених на прикладі діяльності численної групи спортсменів віком від 8 до 30 років і старших, які займалися різними видами спорту, свідчить, що найменший відсоток спортсменів у біоенергетичних групах спостерігався у п'ятій (від 2,6 \% у віці 27-29 років до 6,5 \% у віці 13-15 років, в середньому 4,3 \% від загальної чисельності) та першій групі (від 4,0 \% у віці 13-15 років до 15,4 \% у віці 30 років та старші, в середньому 8,6 \% від загальної чисельності). Найбільший відсоток спортсменів у біоенергетичних групах встановлено у третій групі (від 30,9 \% у віці 8-12 років до 41,5 \% у віці від 24-26 років, у середньому 39,4 \%). У спортсменів, які відносяться до другої та четвертої груп, протягом визначних вікових періодів також спостерігаються несуттєві коливання їх відсоткового співвідношення. Середній показник вікової належності спортсменів до певної біоенергетичної групи, що становив у четвертій групі 17,6 \%, відрізнявся суттєво від аналогічних показників у п'ятій, третій та першій групах. Середній показник вікової належності спортсменів до певної біоенергетичної групи, що становив у другій групі 30,1%, суттєво відрізнявся від аналогічних показників спортсменів першої, четвертої та п'ятої груп, але не суттєво від показника спортсменів, які відносилися до третьої біоенергетичної групи, що свідчить в цілому про достатньо високу ідентичність спортсменів другої та третьої біоенергетичних груп.

Отже, у динаміці показників енергозабезпечення діяльності спортсменів встановлено суттєву різницю між співвідношенням спортсменів таких біоенергетичних груп, як 1-5, 1-4, 1-3, 1-2; 2-5, $2-4,2-1 ; 3-5,3-3,3-1$, та несуттєву між 2-3.

Аналогічні результати отримані нами за підсумками досліджень щодо співвідношення у біоенергетичних групах людей, які не займалися спортивною діяльністю.

Висновки щодо належності людей до певних біоенергетичних груп покладені в основу формування програмного алгоритму визначення їхніх біоенергетичного, медичного, психологічного, професійного та соціального статусів без застосування методів дослідження, що потребують від людей у процесі виконання відповідних тестів надання досліднику інформації про особливості прояву їхньої особистої діяльності, а також додаткового фізичного, психічного та інтелектуального напруження.

3 метою підтвердження припущення щодо доцільності застосування розроблених показників енергозабезпечення людини для контролю за поточним та оперативним станом її здоров'я проведено спеціальні дослідження щодо їх динаміки та взаємозв'язку з різним функціональним станом людей у процесі їхньої повсякденної діяльності. Так, зокрема вибіркові тестування людей

Таблиця 5

\section{Співвідношення людей різних вікових періодів у біоенергетичних групах, \% (на прикладі спортсменів, $\mathrm{n}=\mathbf{2 8 0 8}$ )}

\begin{tabular}{|c|c|c|c|c|c|c|c|c|}
\hline \multirow{2}{*}{$\begin{array}{c}\text { Біоенергетична } \\
\text { група }\end{array}$} & $8-12$ & $13-15$ & $16-20$ & $21-23$ & $24-26$ & $27-29$ & $\begin{array}{c}30 \text { і } \\
\text { старші }\end{array}$ & $\begin{array}{c}\text { Середнє значення } \\
\text { за вибіркою }\end{array}$ \\
\hline 5 & 4,8 & 6,5 & 5,1 & 3,0 & 3,0 & 2,6 & 3,8 & 4,3 \\
\hline 4 & 19,1 & 23,6 & 18,7 & 15,0 & 15,5 & 17,9 & 15,4 & 17,6 \\
\hline 3 & 30,9 & 39,3 & 40,3 & 36,0 & 41,5 & 36,0 & 38,5 & 39,4 \\
\hline 2 & 33,3 & 26,6 & 28,8 & 36,1 & 29,6 & 32,3 & 26,9 & 30,1 \\
\hline 1 & 11,9 & 4,0 & 7,1 & 9,9 & 10,4 & 11,2 & 15,4 & 8,6 \\
\hline
\end{tabular}


з використанням методики «D\&K-TEST» під час найбільш розповсюджених у соціальному середовищі застудних та інфекційних захворювань, ступінь яких оцінюється за динамікою аксилярної температури, свідчать, що з її підвищенням до 37,9 ${ }^{\circ} \mathrm{C}$ спостерігається тенденція до поступового погіршення переважної більшості показників енергозабезпечення, та зокрема ANAMC, максимум якого настав на 5-ту добу та становив -20\% від індивідуальної моделі хворого. У подальшому розвитку захворювання спостерігається поступове поліпшення зазначеного показника, незважаючи на другу хвилю підвищення аксилярної температури тіла. У заключній фазі захворювання спостерігалося зменшення аксилярної температури тіла до фізіологічної норми, а показник ANAMC після короткострокового погіршення до -17 \% від індивідуальної моделі підвищився до +10 \%, після чого досягнув межі допустимих коливань (рис. 1).
Аналогічні приклади залежності зазначених показників від стану здоров’я спостерігалися в інших людей різного віку, статі та професійної приналежності.

Таким чином, динаміка показників енергозабезпечення м’язової діяльності людини, зокрема такого показника, як анаеробна метаболічна ємність (ANAMC), свідчить про його високу інформаційну надійність та можливість використання для контролю за динамікою поточного і оперативного стану здоров'я.

3 метою подальшого вивчення особливостей динаміки показника енергозабезпечення (ANAMC) в умовах максимального прояву функціональних можливостей людини вивчалися його зміни у процесі проведення ударного тренування в бігу на 400 м з бар’єрами, спрямованого на розвиток спеціальної витривалості, що було передбачено планом підготовки спортсменки Т. до літніх Олімпійських
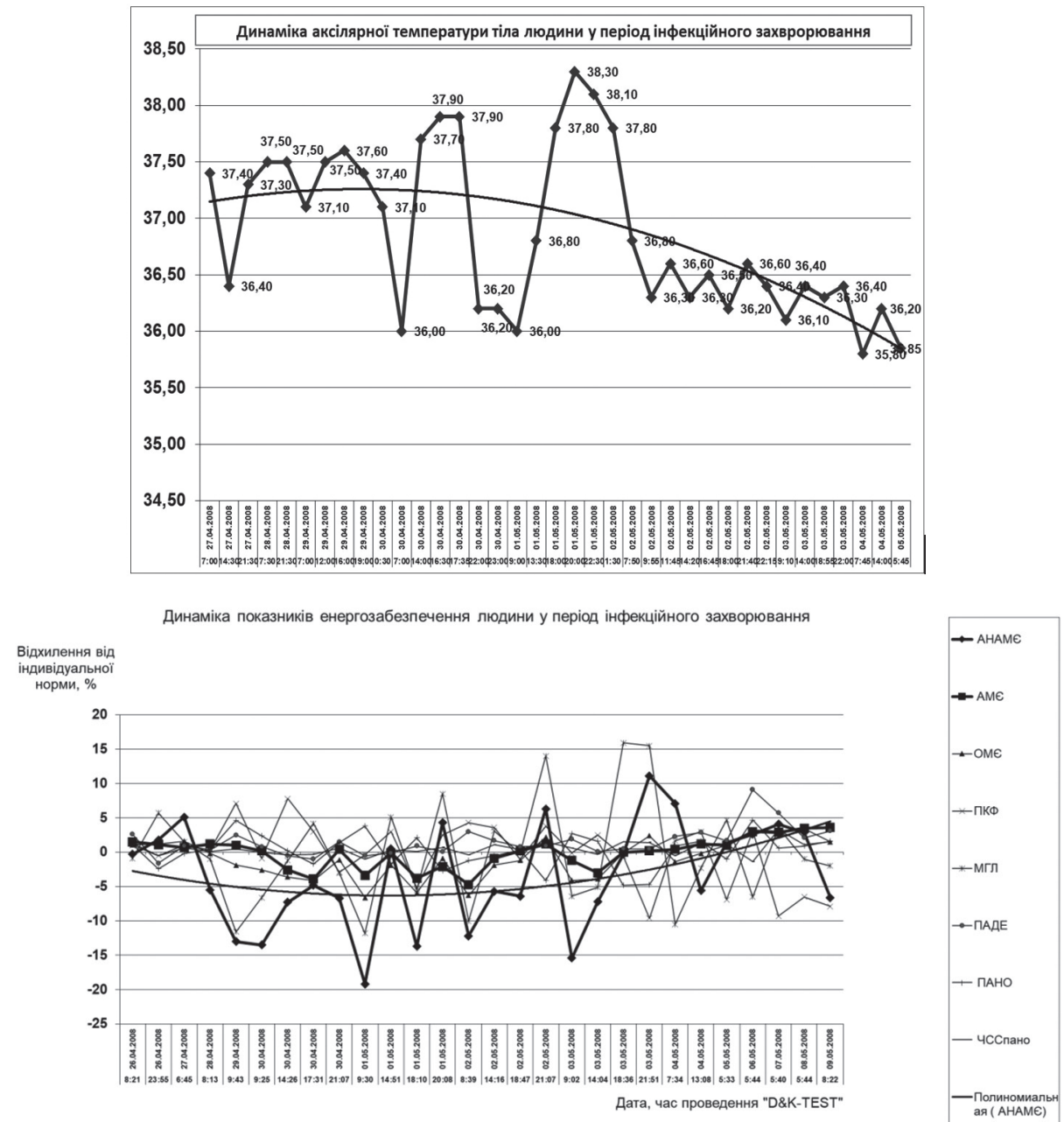

Рис. 1. Динаміка аксілярної температури тіла людини та показників її енергозабезпечення у період інфекційного захворювання 
ігор 2006 року в Афінах, яка у подальшому стала бронзовою призеркою Олімпіади. 3 цією метою перед початком тренування проведено оперативне тестування спортсменки за методикою «D\&KTEST», у результаті якого з'ясувалося, що показник ANAMC виявився на 20 \% гіршим від індивідуальної модельної величини спортсменки. На підставі отриманої оперативної інформації особистий тренер спортсменки погодив перенести тренування на інший час. Повторне тестування показало, що показник ANAMC відрізнявся від індивідуальної моделі на -1 \%. Таке відхилення відповідало завданням запланованого тренування. У подальшому після закінчення кожного з трьох проведених забігів та на 20-й хвилині відпочинку після кожного з них здійснювалося вимірювання показника ANAMC у комплексі з іншими показниками.

Аналіз динаміки показника ANAMC відносно індивідуальної модельної характеристики спортсменки у ході проведення 1, 2-го та 3-го забігів показав наявність прогресивної динаміки його погіршення, що становило відповідно 33 \%, -31 \% та -30 \%. При цьому через кожні 20 хвилин відпочинку після кожного забігу зазначений показник перевищував або відновлювався до індивідуального модельного рівня та становив відповідно +7 \%, +1 \% та -1 \%. В цілому динаміка ANAMC свідчила про його позитивні зрушення, що суб’єктивно підтвердила спортсменка після закінчення 3-го забігу (рис. 2).

Аналогічні дослідження проведені упродовж контрольних тренувань спортсменів з біатлону, лижних гонок, спортивної гімнастики та інших видів спорту.

Висока інформативність показників енергозабезпечення, зокрема ANAMC, щодо адекватності динаміки ступеню впливу на організм спортсмена виконаної тренувальної та змагальної роботи виявлена у процесі довгострокового застосування методики «D\&K-TEST» під час підготовки до зимових Олімпійських ігор 2006 року в Турині. Зокрема встановлено, що великий обсяг тренувальної роботи у підготовчому періоді призводить до зменшення поточного показника ANAMC до -50 \% відносно індивідуальної моделі, та навпаки, ці показники підвищувалися до 50 \% у періоді відновлення.

На етапі безпосередньої підготовки до Олімпійських ігор (січень-лютий) діапазон коливань зазначеного показника анаеробної метаболічної ємності ANAMC значно звузився від +20 \% до -20 \%, а участь у змаганнях зимової Олімпіади співпала з фазою підвищеного енергозабезпечення організму спортсменки. Результатом такого планування підготовки стало здобуття спортсменкою двох золотих олімпійських нагород (рис. 3).

Важливим показником життєдіяльності людини $€$ кислотно-основна рівновага організму, показником якої являється рівень накопичення лактату крові. Для з'ясування наявного зв'язку розроблених показників енергозабезпечення діяльності людини 3 рівнем лактату проведено спеціальні дослідження за участю боксерів високої кваліфікації, для яких перед початком ударного тестування проведено тестування з використанням методики «D\&K-TEST», а після його закінчення вимірювався рівень лактату в крові.

Аналіз динаміки рівня лактату відповідно до біоенергетичних груп спортсменів показав, що найбільша його концентрація спостерігалася у боксерів другої (13,7 ммоль/л), першої (12,4 ммоль/л) та четвертої (11,2 ммоль/л) груп, а найменша - у боксерів п’ятої (8,3 ммоль/л) та третьої (10,3 ммоль/л) біоенергетичних груп (рис. 4).

Отже, проведені дослідження свідчать про наявний взаємозв'язок між таким показником енергозабезпечення людини, як її належність до певної біоенергетичної групи, з показником лактату крові, від рівня якого залежить швидкість відновлення організму людини упродовж та після виконання роботи високої інтенсивності. Такі дані дозволили конкретизувати розроблений нами для біоенергетичного паспорта людини алгоритм професійної та соціальної діяльності людей, які належать до різних біоенергетичних груп, яким визначається, що особистості, які відносяться до п’ятої, четвертої та частково третьої біоенергетичних груп володіють найбільш високим рівнем працездатності під час виконання навантажень високої інтенсивності.

Підтвердженням ефективності використання інших показників енергозабезпечення людини свідчать результати довгострокового однорічного експерименту, у результаті якого встановлено щільний зв’язок між оперативною оцінкою показника СРН (потужність креатинфосфатного джерела енергозабезпечення м’язової діяльності), який регламентує силову витривалість людини, та максимальною кількістю віджимань в упорі лежачи. Для цього перед проведенням віджимання здійснювалося тестування за методикою «D\&K-TEST». Як свідчить аналіз отриманих результатів, найбільша кількість 


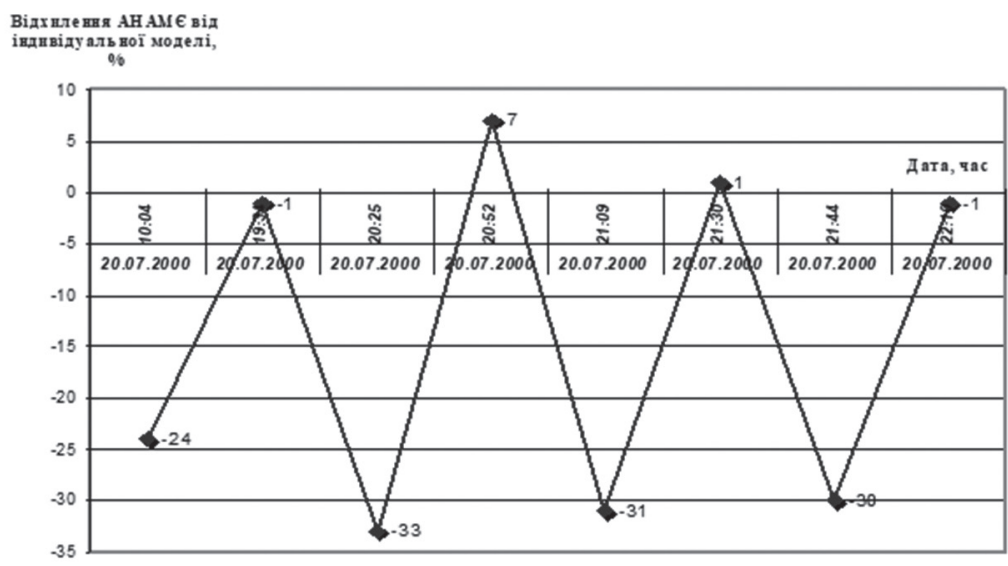

Рис. 2. Динаміка показника ANAMC у спортсменки Т. у ході проведення тренування з розвитку спеціальної витривалості в бігу на 400 м з бар’єрами

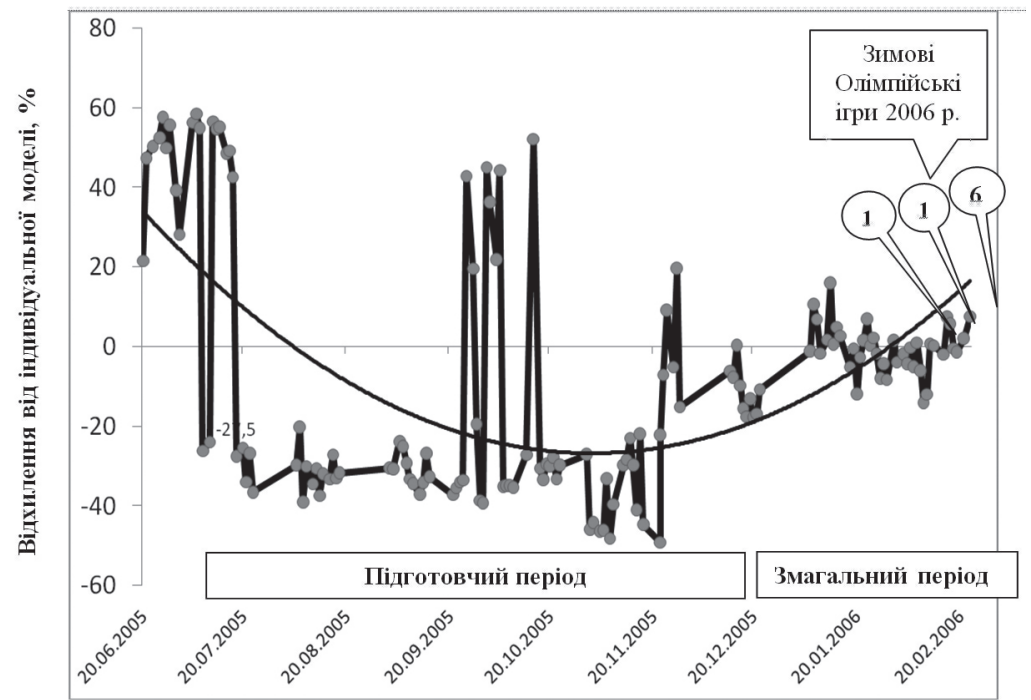

Рис. 3. Динаміка анаеробних можливостей (ANAMC) у дворазової олімпійської чемпіонки з лижних гонок в Турині Х. Ш. у спортивному сезоні 2005-2006 років

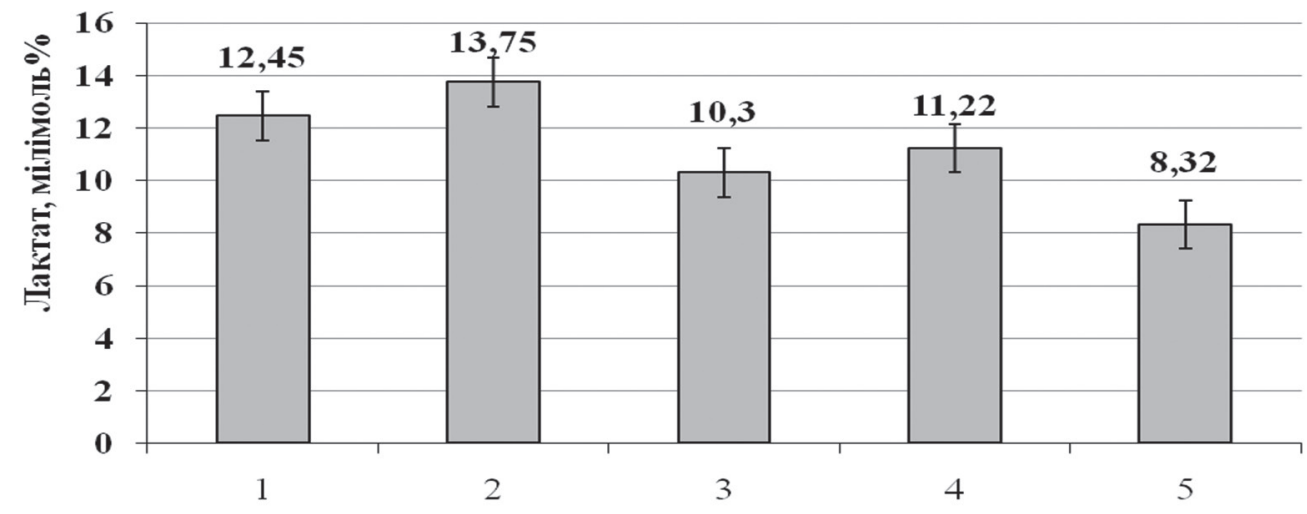

Біоенергетичні групи

Рис. 4. Рівень лактату в крові боксерів після ударного навантаження, що відносяться до різних біоенергетичних груп, визначених за методикою «D\&K-TEST» 
віджимань припадає на оцінку показника 5 балів, найменша - 1 бал (табл. 6).

Це дає можливість обгрунтувати систему планування обсягів фізичних навантажень для спортсменів, завдяки якій в оперативному режимі без використання спеціальних методик оцінювалася ефективність використання засобів і методів тренування для розвитку фізичних якостей, визначався ступінь відновлення організму та стан готовності до проведення наступного тренування залежно від індивідуального коливання показників «D\&KTEST». Пропонуються критерії для корегування обсягів фізичних навантажень, що можуть використовуватися у практиці контролю за руховою активністю людей інших соціальних груп залежно від оперативної динаміки відхилення показників енергозабезпечення від їхньої індивідуальної моделі (табл. 7).

Отже, встановлено, що фізичні навантаження різної переважної спрямованості та потужності односпрямовано впливають на динаміку показника ANAMC та комплексу інших показників енергозабезпечення діяльності людини.

Виявлено дев'ять найбільш ефективних показників енергозабезпечення м'язової діяльності людини, розроблено п’ятибальну систему оцінки їхніх параметрів та встановлено п'ять біоенергетичних груп, до яких відносяться люди з достовірно різними індивідуальними рівнями енергозабезпечення організму.

Результати проведених досліджень свідчать, що розроблені показники та параметри енергозабезпечення діяльності людини адекватно співвідносяться зі станом їхнього здоров’я, ступенем впливу на організм факторів зовнішнього середовища, однонаправлено реагують на прояви таких впливів незалежно від віку, статі, професійної та соціальної приналежності людини, що забезпечує універсальність їх використання, а також створює необхідне підгрунтя для розроблення відповідних алгоритмів керування працездатністю людини.

Особливості динаміки біоенергетичних показників та їхніх параметрів, характер зв'язку між ними у різних проявах життєдіяльності людини покладено в основу розроблення біоенергетичного паспорта людини.

Структура біоенергетичної складової МЕП. Суспільна потреба у наявності біоенергетичного паспорта полягає у необхідності повсякденного зовнішнього, внутрішнього контролю та самоконтролю за раціональним використанням людьми індивідуальних можливостей організму, оскільки

Таблиця 6

Залежність максимальної кількості віджимань в упорі лежачи від потужності креатинфосфатного джерела м’язової діяльності організму, визначеного за методикою «D\&K-TEST»

\begin{tabular}{|c|c|c|c|c|c|}
\hline Оцінка оперативного стану СРН, бали & 1 & 2 & 3 & 4 & 5 \\
\hline Кількість віджимань в упорі лежачи & 50,0 & 56,9 & 57,2 & 69,7 & 74,9 \\
\hline
\end{tabular}

Таблиця 7

Критерії для корегування обсягів фізичних навантажень людей залежно від ступеню відхилення оперативних показників енергозабезпечення від індивідуальної моделі

\begin{tabular}{|c|c|c|c|c|}
\hline \multirow{2}{*}{ 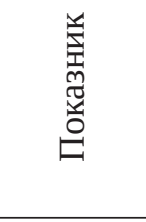 } & \multirow[t]{2}{*}{$\begin{array}{c}\text { Діапазон відхилення оперативно- } \\
\text { го показника від індивідуальної } \\
\text { моделі, \% }\end{array}$} & \multicolumn{3}{|c|}{$\begin{array}{c}\text { Рекомендований обсяг зменшення планового наванта- } \\
\text { ження з урахуванням відхилення оперативного показни- } \\
\text { ка від індивідуальної моделі, \% }\end{array}$} \\
\hline & & на $30 \%$ & на $70 \%$ & скасування \\
\hline ANAMC & від +57 до -57 & -15 & -35 & $>-35$ \\
\hline AMC & від +33 до -30 & -8 & -16 & $>-16$ \\
\hline GMC & від +24 до -30 & -15 & -30 & $>-30$ \\
\hline $\mathrm{CPH}$ & від +63 до -61 & -18 & -46 & $>-46$ \\
\hline GL & від +46 до -40 & -15 & -35 & $>-35$ \\
\hline MOC & від +26 до -23 & -4 & -8 & $>-8$ \\
\hline
\end{tabular}

Примітка. У разі позитивного відхилення показника енергозабезпечення від індивідуальної моделі: а) у спортивній діяльності виконуються обсяги запланованих навантажень з урахуванням індивідуальних планів підготовки; б) у професійній та соціальній сферах — з урахуванням виробничих планів людини 
реалії сьогодення свідчать про високий рівень напруженості їх діяльності на професійному, соціальному та побутовому рівнях.

Структура та зміст біоенергетичної частини МЕП формуються на основі даних тестування людини 3 використанням методики «D\&K-TEST», що формалізується в індивідуальному протоколі дослідження. Зокрема включається така інформація:

- якісна і кількісна характеристика параметрів і показників системи енергозабезпечення м'язової діяльності людини;

- індивідуальні параметри показників енергозабезпечення людини;

- схильність людини до біоенергетичної групи;

- показники серцевої діяльності людини.

3 урахуванням належності людини до біоенергетичної групи, різних співвідношень ії індивідуальних параметрів показників енергозабезпечення та відповідних програмних алгоритмів, що всебічно характеризують повсякденні прояви життєдіяльності людини, у паспорті формуються біоенергетичний, медичний, психологічний, професійний та соціальний профілі людини, зміст яких надається перспективному (прогностичному) та ретроспективному аспектам.

Біоенергетичний профіль людини передбачає інформацію щодо належності до біоенергетичної групи, наявності у неї переважного типу енергозабезпечення поточної і оперативної діяльності та особливостей його використання.

У медичному профілі надається інформація щодо схильності людини до певного типу захворювань, травматизму та ризику їх виникнення, рекомендацій стосовно особливостей використання різних систем харчування.

Психологічний профіль людини передбачає надання інформації щодо її психологічного портрету, темпераменту, психосоціотипу, способів інформаційного самозабезпечення та прийняття рішення, головних рис характеру та образу життя, сумісності з іншими людьми для формування творчих колективів з метою вирішення спеціальних завдань.

У професійному кластері зосереджена інформація стосовно схильності людини до певної сфери діяльності, стилю керівництва, служби у військових формуваннях, занять видами фізкультурно-оздоровчої та спортивної діяльності, надійності керування різними транспортними засобами тощо.

Соціальний кластер передбачає інформацію щодо створення сім'ї, організації відпочинку, використання раціональних механізмів регулювання міжособистісних та міжгрупових відносин, тощо.

Доцільність розроблення біоенергетичної складової МЕП відповідає вимогам існуючих теоретичних положень, а також висновкам наших спостережень щодо формалізації дієвого контролю за динамікою працездатності людини в онтогенезі, оскільки її рівень у окремої людини та соціального колективу в цілому впливає на ефективність взаємовідносин продуктивних сил і виробничих відносин, забезпечує реалізацію ними вимог суспільства щодо виконання обсягів та інтенсивності різновидів робіт, сприяє згуртованості професіональних і творчих колективів, обумовлює міцність та надійність міжособистісних стосунків в сім'ях, а також взаємовідносин в інших соціальних осередках.

Нагальною потребою щодо впровадження біоенергетичного паспорта людини в сучасних умовах розвитку суспільства у повсякденне життя $є$ також необхідність систематизації алгоритмів поліпшення її життєдіяльності (працездатності) та їх синхронізації відповідно до індивідуальних можливостей систем енергозабезпечення шляхом використання нових інформаційних та біотехнологій. При цьому біотехнологіям відводиться особливо важливе значення, оскільки вони базуються на індивідуальних показниках системи енергозабезпечення м'язової та серцево-судинної діяльності людини. Саме у цих системах відбуваються безперервні анаболічні процеси, що супроводжуються репродукцією енергії 3 використанням потужностей креатинфосфатного, гліколітичного і аеробного джерел, та катаболічні, що забезпечують утилізацію шкідливих для діяльності організму метаболітів, зокрема молочної кислоти, які утворюються унаслідок споживання енергії. Швидкість та ефективність утилізаційних процесів обумовлені рівнем анаеробної, аеробної та загальної метаболічної ємності зазначених систем (особливо серцево-судинної, яка споживає для живлення серцевого м'язу молочну кислоту) [9, 15].

Результати проведених досліджень підтверджуються в працях інших науковців. Зокрема у непрямих дослідженнях, проведених для визначення енергозабезпечення організму за методикою Вільсона, у 38 спортсменок та 18 спортсменів виявлено позитивний кореляційний взаємозв'язок між співвідношенням висоти зубців R i S в грудних відведеннях: V3R - 3 показниками біопсії 
( $\mathrm{r}=0,9)$; V2 — 3 рівнем лактату крові $(\mathrm{r}=0,9)$; V6 3 величиною максимального споживання кисню $(\mathrm{r}=0,9)[13]$.

Встановлено також взаємозв'язок генетичної схильності серця спортсменів до роботи в анаеробних та аеробних умовах м'язової діяльності 3 функціонально-моторною асиметрією тіла людини у проявах спеціальних локомоцій та фізіономіки [17, 18].

В дослідженнях, присвячених виявленню взаємозв'язку показників «D\&K-TEST» 3 типом темпераменту (методика Г. Айзенка) та ігровим амплуа футболістів, встановлено, що переважній більшості спортсменів, які відносилися до 1-ї та 2-ї біоенергетичних груп, у 91 \% були притаманні холеричний і сангвіно-холеричний тип темпераменту та амплуа нападників, до 3-ї групи - сангвінохолеричний і сангвінічний з амплуа напівзахисників, до 4-ї та 5-ї груп - сангвіно-меланхолічний, сангвіно-флегматичний, меланхолічний і флегматичний з переважним амплуа напівзахисників, захисників та голкіперів. Виявлено також різний ступінь належності спортсменів у видах спорту до біоенергетичних груп. Зокрема в ігрових видах спорту переважали спортсмени 2-ї та 3-ї біоенергетичних груп, у видах єдиноборств спостерігалося рівне співвідношення спортсменів, які відносилися до 2, 3-ї та 4-ї груп, у важкій атлетиці були присутні спортсмени 2, 3, 4-ї та 5-ї біоенергетичних груп [7].

Окремими дослідниками доведено наявність впливу рівня енергозабезпечення м'язової діяльності, визначеного за методикою Вільсона, на прояв техніко-тактичної майстерності лижниківгонщиків під час участі у змаганнях [3].

Наші дослідження доповнюють висновки відомих спеціалістів у сфері біології та медицини щодо проявів різних форм активності людини, зокрема спортивної, яка посідає друге місце за ступенем впливу на організм після військових дій; свідчать, що рівень співвідношення процесів репродукції та утилізації в організмі людини забезпечує їй підсвідому синхронізацію напруженості повсякденної професійної та соціальної діяльності 3 такими важливими генетично обумовленими критеріями функціональних і резервних можливостей, як ефективність, відновлюваність та економічність [1, 5, 10, 14, 20].

Вагомим теоретичним та практичним підгрунтям для запровадження біоенергетичної складової МЕП є результати дослідження у сфері спортивної медицини, фізичної культури та спорту, які дозволили науково обгрунтувати факторну структуру фізичної працездатності атлетів і її неоднорідність та сформувати систему моніторингу та нові принципи експрес-контролю аеробного й анаеробного обміну [3], розробити відповідні способи та пристрої реєстрації показників і параметрів енергозабезпечення діяльності спортсменів $[6,12,19]$ i біоенергетичний паспорт спортсмена [2].

Отже, наведені наукові дані щодо використання особливостей системи енергозабезпечення організму створюють надійне теоретико-методичне підгрунтя та не суперечать потребі щодо впровадження біоенергетичного паспорта для людей різного віку, статі та соціальних груп із метою оптимізації їхньої повсякденної діяльності в сучасних умовах розвитку суспільства.

\section{Висновки.}

1. Запропоновано біоенергетичну складову МЕП, що може знайти широке застосування в медичних профілактичних і лікувальних установах різного профілю, на підприємствах, у спортивних та інших закладах при автоматизованому оцінюванні функціонального стану окремих людей, а також при статистичних дослідженнях і визначенні різних соціальних генотипічних груп населення за їхніми фізичними, інтелектуальними та професійними здібностями.

2. Виявлено дев'ять найбільш ефективних показників енергозабезпечення м’язової діяльності людини, розроблено п’ятибальну систему оцінювання їх параметрів і встановлено п’ять біоенергетичних груп, до яких відносяться люди 3 достовірно різними індивідуальними рівнями енергозабезпечення організму.

\section{Література.}

1. Биохимия мышечной деятельности / Н. И. Волков, Э. Н. Несен, А. А. Осипенко, С. Н. Корсун. - К. : Олимпийская литература, 2000. - 504 с.

2. Биоэнергетический паспорт спортсмена / В. Карленко, Б. Карленко, Н. Карленко, А. Фокин // Спорт. Олимпизм. Здоровье : материалы Международного научного конгресса (Кишинев, 5-8 октября 2016 г.). - 2016. - T. II. - C. 518-524.

3. Влияние биоэлектрической активности сердца на технико-тактическое мастерство в лыжных гонках / В. П. Карленко, А. В. Веркалец, Н. В. Карленко [и др.] // Людина, спорт і здоров’я : матеріали II Bсеукраїнського з'їзду фахівців спортивної медицини та лікувальної фізкультури України, присвяченого 60-річчю лікарсько-фізкультурної служби України. — Київ, 2008. — С. 44-46. 
4. Генетический паспорт человека - значение и выполнение [Электронный ресурс] / GlobalScience. ru. - 10.10.2014. - Режим доступа : http:// globalscience.ru/article/read/25348/.

5. Душанин С. А. Ускоренные методы исследования энергетического метаболизма мышечной деятельности : методические рекомендации / С. А. Душанин, Ю. В. Береговой, В. Г. Мигулева. - К. : Здоров'я, 1984. - 27 с.

6. Карленко В. П. Использование компьютерной технологи D\&K-TEST в практике подготовки квалифицированных спортсменов / В. П. Карленко, Н. В. Карленко. - М. : Всероссийский научно-исследовательский институт физической культуры и спорта, 2003. - С. 134-136.

7. Медико-біологічне забезпечення підготовки спортсменів збірних команд України з олімпійських видів спорту : навчально-методичний посібник / заг. ред. О. А. Шинкарук. - К. : Олімпійська література, 2009. - 144 с.

8. Медицинский паспорт [Электронный ресурс] // Здоровье. - 1988. - № 2. - Режим доступа : http:// lechebnik.info/484/20.htm.

9. Меерсон Ф. З. Адаптация сердца к большой нагрузке и сердечная недостаточность / Ф. З. Меерсон. - М. : Наука, 1975. - 263 с.

10. Михайлов В. М. Нагрузочное тестирование под контролем ЭКГ: велоаргометрия, тредмилл-тест, степ-тест, ходьба /В. М. Михайлов. - Иваново : А-Гриф, 2005. - 439 с.

11. Паспорт здоровья школьника [Электронный ресурс] / Википедия. - 21 ноября 2017. — Режим доступа : https://ru.wikipedia.org/wiki/Паспорт_здоровья_школьника.

12. Пат. 57675 Україна. МПК7 А61B5/00, А61B5/02, A61B5/0452, А61B5/0456. Спосіб експрес-діагностики функціонального стану і резервних можливостей організму та пристрій для його реалізації / Карленко В. П., Карленко Б. В., Карленко Н. В. № 2002108583 ; заявл. 29.10.2002 ; опубл. 16.06.2005, Бюл. № 6.

13. Перхуров А. М. Очерки донозологической функциональной диагностики в спорте / А. М. Перхуров. М. : РАСМИРБИ, 2006. - С. 5.

14. Платонов В. М. Система энергообеспечения мышечной деятельности / В. М. Платонов // Периодизация спортивной тренировки. Общая теория и ее практическое применение. - К. : Олимпийская литература, 2013. - С. 140-161.

15. Скулачев В. П. Законы биоэнергетики / В. П. Скулачев // СОЖ. - 1997. — № 1. - С. 9-14.

16. Соболєв В. Функціонально-моторна асиметрія тіла людини у проявах спеціальних локомоцій, фізіогноміки та генетичної схильності серця до роботи в анаеробних та аеробних умовах з м'язової діяльності / В. Соболєв, К. Макаренко, Ю. Соболєв //
Теорія і методика фізичного виховання і спорту. 2004. — № 1. - С. 111-118.

17. Соболев В. Л. Экспресс-диагностика генетической предрасположенности человека к мышечной работе в анаэробных и аэробных условиях по данным специальных упражнений и физиогномики / В. Л. Соболев // IX Міжнародний науковий конгрес «Олімпійський спорт і спорт для всіх»(Київ, 2023 вересня 2005 р.) : тези доп. - К., 2005.— С. 725.

18. Соколова Н. И. Тестирование индивидуальной подготовки спортсменов высокой квалификации с использованием методики D\&K-TEST / Н. И. Сoколова, Н. В. Криволап, А. В. Вакула // Спортивна наука Донбасу : матеріали науково-практичної конференції «Актуальні проблеми науково-методичного i медико-біологічного забезпечення спортивної підготовки» (Донецьк, 27-28 листопада 2004 р.). Донецьк, 2004. - С. 232-236.

19. Pat. US 6920348B2. Method and apparatus for determining metabolic factors from an elektrocardiogram / Vasin E., Gelfenbain A. — № US 10/364,647;decl. 31.01.2003 ; publ. 19.07.2005.

20. Stenger V. J. The physics of 'alternative medicine'. Bioenergetic fields / V. J. Stenger // The Scientific Review of Alternative Medicine (SRAM). — 1999. — Vol. 3, No. 1.

\section{References.}

1. Volkov, N. I., Nesen, E. N., Osipenko, A. A., \& Korsun, S. N. (2000). Biokhimiya myshechnoi deyatel'nosti [Biochemistry of muscular activity]. Kyiv: Olimpiiskaya literatura (Olympic literature).

2. Karlenko, V., Karlenko, B., Karlenko, N., \& Fokin, A. (2016). Bioenergeticheskii pasport sportsmena [Athlete's bioenergetic passport]. In Sport. Olimpizm. Zdorov'e (Sport. Olympism. Health): materials of the International Scientific Congress (Chisinau, October 5-8, 2016) (pp. 518-524), 2.

3. Karlenko, V. P., Verkalets, A. V., Karlenko, N. V., Dekhtyarev, Yu. P., \& Nesterov, V. N. (2008). Vliyanie bioelektricheskoi aktivnosti serdtsa na tekhnikotakticheskoe masterstvo v lyzhnykh gonkakh [Influence of the bioelectrical activity of the heart on technical and tactical skills in ski races]. In Lyudina, sport i zdorov'ya (Man, sport and health): materials of the II All-Ukrainian Congress of Sports Medicine and Physiotherapy Physicists of Ukraine dedicated to the 60th anniversary of the medical and athletic service of Ukraine (pp. 44-46). Kyiv.

4. Geneticheskii pasport cheloveka - znachenie i vypolnenie [Genetic passport of a person — meaning and fulfillment]. (2014, October 10). Retrieved April 15, 2018 from GlobalScience.ru, http://globalscience.ru/ article/read/25348/.

5. Dushanin, S.A., Beregovoi, Yu. V., \& Miguleva, V.G.(1984). Uskorennye metody issledovaniya energeticheskogo 
metabolizma myshechnoi deyatel'nosti [Accelerated methods for studying the energy metabolism of muscle activity]: guidelines. Kyiv: Zdorov'ya (Health).

6. Karlenko, V. P., \& Karlenko, N. V. (2003). Ispol'zovanie komp'yuternoi tekhnologi D\&K-TEST v praktike podgotovki kvalifitsirovannykh sportsmenov [The use of computer technology D\&K-TEST in the practice of training qualified athletes]. Moscow: Vserossiiskii nauchno-issledovatel'skii institut fizicheskoi kul'tury i sporta (All-Russian Scientific Research Institute of Physical Culture and Sports).

7. Shinkaruk, O. A. (Ed.). (2009). Mediko-biologichne zabezpechennya pidgotovki sportsmeniv zbirnikh komand Ukraini z olimpiis'kikh vidiv sportu [Medical and biological support for the training of athletes of national teams of ukraine in olympic sports]: teaching aid. Kyiv: Olimpiis’ka literatura (Olympic literature).

8. Meditsinskii pasport [Medical passport]. (1988). Retrieved April 15, 2018 from Zdorov'e (Health), 2, http://lechebnik.info/484/20.htm.

9. Meerson, F. Z. (1975). Adaptatsiya serdtsa k bol'shoi nagruzke i serdechnaya nedostatochnost' [Adaptation of the heart to a large load and heart failure]. Moscow: Nauka (Science).

10. Mikhailov, V. M. (2005). Nagruzochnoe testirovanie pod kontrolem EKG: veloargometriya, tredmill-test, step-test, khod'ba [Load testing under ECG control: veloargometry, treadmill test, step-test, walking]. Ivanovo: A-Grif.

11. Pasport zdorov'ya shkol'nika (2017, November 17). In Wikipedia: The free encyclopedia. Retrieved April 15, 2018 from: https://ru.wikipedia.org/wiki/Pasport_ zdorov'ya_shkol'nika.

12. Karlenko, V. P., Karlenko, B. V., \& Karlenko, N. V. (2005). Sposib ekspres-diagnostiki funktsional'nogo stanu i rezervnikh mozhlivostei organizmu ta pristrii dlya iogo realizatsii [The method of express diagnostics of the functional state and reserve capabilities of the body and the device for its implementation]. Pat. 57675 Ukraine. MPK7 A61V5/00, A61V5/02, A61V5/0452, A61V5/0456. No. 2002108583; decl. 29.10.2002; publ. 16.06.2005, Bul. No. 6.

13. Perkhurov, A. M. (2006). Ocherki donozologicheskoi funktsional'noi diagnostiki $\mathrm{v}$ sporte [Essays of prenosological functional diagnosis in sports]. Moscow: RASMARSD.

14. Platonov, V. M. (2013). Sistema energoobespecheniya myshechnoi deyatel'nosti [System of energy supply of muscular activity]. In Periodizatsiya sportivnoi trenirovki. Obshchaya teoriya i ee prakticheskoe primenenie (Periodization of sports training. General theory and its practical application) (pp. 140-161). Kyiv: Olimpiiskaya literatura (Olympic literature).

15. Skulachev, V. P. (1997). Zakony bioenergetiki. Sorosovskii obrazovatel'nyi zhurnal (Soros educational journal), 1, 9-14.
16. Sobolev, V., Makarenko, K., Sobolev, Yu. (2004). Funktsional'no-motorna asimetriya tila lyudini u proyavakh spetsial'nikh lokomotsii, fiziognomiki ta genetichnoi skhil'nosti sertsya do roboti v anaerobnikh ta aerobnikh umovakh z m'yazovoi diyal'nosti [Functional and motor asymmetry of the human body in the manifestations of special locomotion, physiognomy and genetic predisposition of the heart to work in anaerobic and aerobic conditions with muscular activity]. Teoriya i metodika fizichnogo vikhovannya i sportu (Theory and methods of physical education and sports), 1, 111-118.

17. Sobolev, V. L. (2005). Ekspress-diagnostika geneticheskoi predraspolozhennosti cheloveka $\mathrm{k}$ myshechnoi rabote $\mathrm{v}$ anaerobnykh I aerobnykh usloviyakh po dannym spetsial'nykh uprazhnenii i fiziognomiki [Express diagnostics of a person's genetic predisposition to muscular work in anaerobic and aerobic conditions according to special exercises and physiognomy]. In IX International Scientific Congress «Olympic Sport and Sport for All» (Kyiv, September 20-23, 2005): abstracts (p. 725). Kyiv.

18. Sokolova, N. I., Krivolap, N. V., \& Vakula, A. V. (2004). Testirovanie individual'noi podgotovki sportsmenov vysokoi kvalifikatsii s ispol'zovaniem metodiki D\&KTEST [Testing of individual training of high-qualified athletes using D\&K-TEST]. In Sportivna nauka Donbasu (Sports Science of Donbass): materials of the scientific and practical conference «Actual problems of scientific and methodological and medical and biological support of sports training» (Donetsk, November 27-28, 2004) (pp. 232-236). Donets'k.

19. Vasin, E., Gelfenbain, A. (2005). Pat. US 6920348 B2. Method and apparatus for determining metabolic factors from an elektrocardiogram. No. US 10/364,647; decl. 31.01.2003 ; publ. 19.07.2005.

20. Stenger, V. J. (1999). The physics of 'alternative medicine'. Bioenergetic fields. The Scientific Review of Alternative Medicine (SRAM), 3(1). 